\title{
Local economic development and small business failure: the case of a local municipality in South Africa
}

\section{Silas Mukwarami}

Faculty of Management and Law, University of Limpopo, South Africa

Email: msilomuk@gmail.com

\section{Josephat Mukwarami}

Faculty of Business, Cape Peninsula University of Technology, South Africa

Email: jolief2006@yahoo.com

\section{Robertson K. Tengeh*}

Department of Entrepreneurship and Business Management, Cape Peninsula University of Technology, South Africa

Email: tengehr@cput.ac.za

*Corresponding author

\begin{abstract}
Despite concerted efforts to nurture SMMEs through a number of methods, including LED initiatives, a high failure rate persists in South Africa. As the quest for a sustainable solution continues, this paper investigates the challenges that SMMEs face in the context of the Bushbuckridge Local Municipality (BLM). The quantitative approach was adopted for data collection. Through the use of a survey questionnaire, data were collected from a sample of fifty owners/managers who were reached through the stratified sampling technique. The study singled out lack of financial assistance, managerial skills, inaccessible global markets as the most dominant challenges to the development of SMMEs apart a from high crime rate and the fear of xenophobia. Lack of technology and insufficient government support received far lesser approval from participants as these were perceived to have less impact on SMMEs growth. This paper draws attention to the ineffectiveness of LED programmes at the grassroots level with specific reference to rural municipalities.
\end{abstract}

Keywords: local economic development; LED; small business development; SMMEs.

Reference to this paper should be made as follows: Mukwarami, S., Mukwarami, J. and Tengeh, R.K. (2020) 'Local economic development and small business failure: the case of a local municipality in South Africa', Int. J. Business and Globalisation, Vol. 25, No. 4, pp.489-502.

Biographical notes: Silas Mukwarami is an experienced educator with over five years of teaching experience in Zimbabwe and South Africa. He holds a Diploma in Technical and Vocational Education from the Chinhoyi University 
of Technology. He also has a BCom (Honours) in Accounting, Masters of Commerce degree and he currently studying towards Doctor of Commerce (Accounting) degree at the University of Limpopo in South Africa. He has published an article on corporate social responsibility and is working on several projects in the area of sustainability and entrepreneurship. He has a specific interest in the areas of accounting, sustainability, and small business management.

Josephat Mukwarami is an educator, trainer as well a researcher based in Cape Town, South Africa. Grew up in Zimbabwe where he received teacher training at the Chinhoyi Technical Teachers College (1997), majoring in Accounting and Business Studies. He is the holder of the Masters of Technology: Business Administration, Bachelor of Technology: Business Administration, Bachelor of Technology: Education Management, Diploma in Education, and an Executive Diploma in Business Leadership. He taught in Zimbabwe for eight years, and in 2006 he moved to Cape Town where he lectured for two years. In 2008, he got a teaching job with Department of Education in Cape Town, and a teaching job he still holds to date. He has a particular interest in entrepreneurship with an emphasis on small businesses, an area that he has published four articles to date.

Robertson K. Tengeh is a Senior Lecturer and currently heads (acting) the Department of Entrepreneurship and Business Management at the Cape Peninsula University of Technology in South Africa. He has published over 50 articles in peer-reviewed journals. He has also authored book chapters and technical reports. Furthermore, he has presented papers at both local and international conferences. He has supervised and examined considerably. $\mathrm{He}$ sits on the editorial board of many international journals. Within the broad areas of entrepreneurship and management, his research interests include immigrant entrepreneurship, entrepreneurship development, entrepreneurship education, small business management, and strategic management.

\section{Introduction}

Despite inconsistencies in the available empirical data, there is the growing consensus that a flourishing small, medium and micro-sized enterprises (SMMEs) sector is pivotal in addressing the socio-economic issues that plague most economies in the world today. These issues mostly relate to poverty, unemployment, wealth redistribution and economic growth. As long as these issues remain unresolved, so to would SMME development feature in the development agenda of most countries. In fact, Mahembe (2011) and Ramadani et al. (2015) seem to concur that prioritising SMMEs development has gained credence worldwide as the possible approach towards sustainable development. The aforementioned tend to influence the size of the SMME sector depending on the country, and the strategy adopted. For instance, in countries such as India, Philippines, Malaysia and Brazil, SMMEs make-up $60 \%$ of all companies and make a relatively smaller impact, while economies such as the USA, boast of a sizeable SMME sector that contributes to $90 \%$ of the employment is generated (Soni, 2005). Reverting to South Africa, the literature postulates that the prevalence of the socio-economic ills has given rise to the advancement of the SMMEs agenda (Mutyenyoka and Madzivhandila, 2014). 
All things being the same, the contribution of the SMME sector would be quite meaningful as evidence suggests that there are approximately 2.2 million SMMEs (including formal and informal businesses) in South Africa. However, inconsistency in reporting and data make it a daunting task to gauge the real contribution that SMMEs make to the national economy in the context of South Africa. Abor and Quartey (2010) acknowledge that $91 \%$ of the formal businesses in South Africa are SMEs and that they contribute up to $57 \%$ to GDP. Statistics South Africa (2015) reckons that SMMEs contribution to GDP is capped at $40 \%$. The inconsistency apart, the SMME sector has the potential to contribute substantially to job creation, poverty reduction and socio-economic upliftment in South Africa (Tengeh, 2013).

One may argue that the suboptimal performance of the SMMEs in South Africa is not the result of lack of pro-SMME growth initiatives. Perhaps because the performance of the SMMEs sector remains weak despite the numerous pro-SMMEs growth programs rolled out in the last couple of years by the South African government (Meyer, 2014; OECD, 2015; Mukwarami and Tengeh, 2017). Local economic development (LED) initiatives are amongst, the approaches adopted to support the SMME development and growth (Meyer, 2014; Nyawo and Mubangizi, 2015).

Notwithstanding the positive impact of the government's LED initiatives on SMME development, current evidence still suggests that approximately $40 \%$ of new business ventures fail in their first year, while $60 \%$ fail in their second year, and $90 \%$ fail in their first ten years of existence (Morgan, 2012; Bowler et al., 2007; Tengeh and Mukwarami, 2017). The failure of smaller businesses may be due to the confusion among various stakeholders about how SMMEs can be utilised to reduce poverty strategically (Lekhanya, 2015).

While many researchers have investigated the reasons for the poor performance of SMMEs extensively (Mukwarami and Tengeh, 2017; Chimucheka and Mandipaka, 2015; Asoba and Tengeh, 2016) most of these authors have adopted the problem-solution approach, and the locus of these studies have been predominantly urban and semi-urban. This assertion leaves the scope for an investigation that focuses on the rural areas and more so, one that adopts the solution - problem approach. Assuming that SMMEs failure in South Africa remains an inconclusive matter, this study sought to determine the contributing factors in the context of Bushbuckridge Local Municipality (BLM) and to advise accordingly.

\section{Literature review}

\subsection{SMMEs in South Africa}

The development of SMMEs has taken top priority since the demise of apartheid in South Africa. As the engine of economic growth in the country, SMMEs are purported to have the potential to create employment and eradicate poverty in the rural communities (Chimucheka and Mandipaka, 2015). In particular, it is believed that SMMEs have the potential to bring about the requisite change in the economy through its impact on job creation and poverty reduction at the grassroots level (Small Enterprise Development Agency, 2016). One way of ensuring that local communities benefit from the pro-SMMEs initiative is through designing and administering appropriate LED policies. 


\subsubsection{Government's efforts towards SMMEs development}

One of the government's portfolios is to grow the economy, and some do so effectively by supporting SMMEs. Through legislation, the government enacts laws and policies that aim to promote the growth of SMMEs. Some of such instruments include the Local Government Transition Act of 1993, which was amended in 1999; the National Small Business Act 102 of 1996 and Broad-Based Black Economic Empowerment (BBE) Act 53 of 2003. These pieces of legislation have played a considerable role in the growth of the SMME sector, particularly the BBE Act of 2003 which became the first legislation which provided unlimited opportunities to the historically disadvantaged people the opportunity to contribute meaningfully to the economy (Department of Trade and Industry, 2014). Furthermore, the government has attempted to address the skills shortage problems among the existing and potential SMMEs operators through Sectorial Education and Training Authorities (SETAs) which coordinates the up-skilling of the employees (World Bank, 2007).

Considering that SMMEs are mostly confined to certain areas, their growth depends on the LED initiatives driven by the local municipalities (Chimucheka, 2015). As such, the Department of Cooperate Governance and Traditional Affairs (DCOGTA, 2015) postulates that LED policies encourage people to identify business opportunities within their vicinity. To this end, the government attempts to address capacity gaps that may exist within the small business environment. Hence, the LED programs focusing on electrification, improving service delivery, transport issues and regulatory framework, have been prioritised in the effort to curb socio-economic issues (OECD, 2015). Fundamentally, the SMMEs sector has become the focus area of three spheres of the government in its fight against economic inequalities in the country.

SMMEs contribute to economic development by unlocking employment opportunities and mitigating the impact of poverty on the historically disadvantaged communities (Tengeh, 2013, Chimucheka and Mandipaka, 2015). Given the socioeconomic inequalities which are prevalent in the polarised South African communities (Mukwarami et al., 2017), SMMEs become a strategic tool in the fight against poverty at the grassroots level. Through dedicated agencies, the government provides many support programs in the form of sector-specific grants, research and development, and skills development to the youth (OECD, 2015). National Development Plan (NDP) is one of the government's most recent initiative, which aims to eradicate poverty by 2030. Promoting SMMEs development within the designated local economic zones is one of NDP's top priorities. NDP hopes that its efforts may improve annual economic growth by 5\%, and SMMEs would have a significant role to play in achieving this objective by 2030 .

\subsection{Overview of the government's economic development programs}

Since 1994, the South African government responded to the problems of socio-economic injustices by rolling out various economic development programs, including; Reconstruction and Development Programme (RDP) in 1994, which brought positive socio-economic changes to the poor communities by ensuring that poor people have access to essential services like water and housing. In 1996, the Growth, Employment and Redistribution (GEAR) program was established with the same socio-economic agenda as the RDP, but with a specific focus on growing the economy, creating employment and redistributing wealth. Ten years down the line, the Accelerated and 
Shared Growth Initiative (AsgiSA) framework was introduced (in 2006) with the aim of accelerating economic growth through targeted sharing the fruits of the growing economy. Initiated in 2010, the New Growth Plan focused on identifying potential ways of jump-starting the economic growth.

In 2012, the NDP was introduced, and one of its aims was to redress the socio-economic injustices by developing businesses in specific geographical areas. However, the NDP made provision for other complementing economic programs such as Industrial Policy Action Plan, National Infrastructure Plan, as well as the National Industrial Policy Framework (NIPF). The NIPF hoped to facilitate industrialisation by promoting diversification, creating labour-intensive industries, intensifying production in the industries and integrating historically excluded South Africans into the mainstream economy through LED programs (OECD, 2015; National Planning Commission, 2011).

\subsubsection{Pro-SMMEs programs in BLM}

Located in the Mpumalanga province, the BLM is amongst the poorest rural municipalities in South Africa, with an unemployment rate of 52, 2\% (BLM, 2014). Many LED programs have been rolled out at the provincial and local municipality levels in the attempt to mitigate regional poverty. One of such locally initiated programs is the Mpumalanga Economic Growth Agency (MEGA) which was formed through the merger of the Mpumalanga Economic Empowerment Corporation and the Mpumalanga Investment Initiative. MEGA hoped to provide real support SMMEs in the areas of financial assistance, mentorship to enterprises, and the development of cooperatives.

Notwithstanding the province's efforts in promoting SMMEs development and growth, BLM has initiated complementing LED programs which aim to promote the development of SMMEs within its areas of jurisdiction. The most recent of these programs include the Bushbuckridge Clay Brick Manufacturing, Champaign chicken abattoirs, and Rolle Amarula Project (BLM, 2014). Many LED initiatives are earmarked for the previously economically deprived population, such as the allocation of land and revitalisation of the agricultural schemes. Additionally, LED initiatives such as rural electrification, water provision and road construction are aimed to address the existing infrastructure backlog are currently underway (BLM, 2014).

\subsection{Contributions by SMMEs}

From an international perspective, it is believed that SMEs employ on average $65 \%$ of the active population and account for $75 \%$ of total gross job creation (OECD, 2015). In the context of South Africa, the significance and contributions of SMMEs have been well established (Mukumba, 2014) even though unemployment levels remain inordinately high at $26 \%$ and above by international standards. It becomes obvious that SMMEs be the preferred partway to economic growth and socio-economic development in South Africa (OECD, 2015; Edwards and Rankin, 2015).

The Department of National Planning and Evaluation speculates that $90 \%$ of the job will be created by SMEs by 2030 through the NDP. However the South Africa Institute of Chartered Accountants (SAICA, 2015) believes that such an ambitious goal cannot be realised unless the government changes its approach to the development of SMMEs.

A snapshot indicates an increment in the number of people engaged in entrepreneurial activities as of the second quarter of 2015. The associated growth in employment during 
this period could be attributed to those involved in the informal sector, although measuring their contribution is a challenge (Statistics South Africa, 2015). In another direction, there was a steady increase in the contribution of SMMEs to the GDP (Figure 1). All things being equal this may be construed to be an indication of the effectiveness of the pro-SMMEs policies.

Figure 1 SMMEs contribution to GDP in South Africa (see online version for colours)
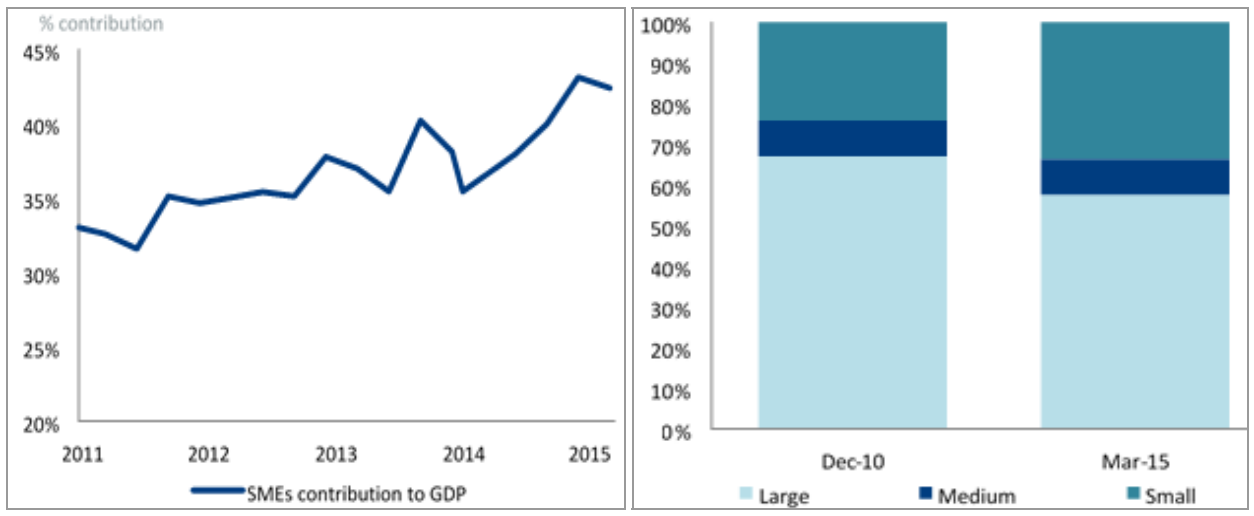

Source: Statistics South Africa (2015, Quarter 2)

\subsection{Challenges faced by SMMEs}

Issues around the survival and growth of SMMEs have gained traction over the years as a result of the impact that they have on the economy. This notwithstanding, SMMEs have to overcome many challenges to survive let alone grow. On this note, SMMEs encounter some problems which are linked to financing, environmental and managerial aspects (Brink et al., 2003; Brinders et al., 2003).

\subsubsection{Financial inaccessibility}

Capital is the lifeblood of the business, and its availability influences the development and growth of SMMEs in every respect. However, reasonable access to financial capital problem remains a major challenge faced by the small business operators around the world as conceived by a number studies (see Tengeh, 2013; Agwa-Ejon and Mbohwa, 2015; Chimucheka and Mandipaka, 2015; Mukwarami and Tengeh (2017). Some authors, including Mutyenyoka and Madzivhandila (2014) are of the opinion that financial aid organisations such as the Khula Enterprise Finance and South African Microfinance Apex Fund (SAMAF) which are supposed to provide financial assistance to small businesses are not effectively functional.

\subsubsection{Lack of business skills}

The availability of capital does not guarantee the success of the business, and intellectual capital is defensibly an important pre-requisite for any business to start up. Along these lines, the extant literature points to the business management skills needed to keep the 
business growing: leadership, financial management, and management of information, networking and human capital management skills (Mukwarami and Tengeh, 2017).

\subsubsection{Insufficient government support and red tape}

SMMEs exist within the jurisdiction of local municipalities, which are responsible for enacting LED policies and promoting the growth of SMMEs. It is thus expected that SMMEs would require the support of three spheres of government, namely local, provincial and national government. The government can influence the growth of SMMEs through the implementation of business-friendly laws and provide various forms of support to the SMMEs. In the same way that the absence of government support inhibits the growth of SMMEs (Fatoki and Garwe, 2010; Chimucheka and Mandipaka, 2015), so too do unfriendly labour laws negatively impact well-designed pro-SMMEs initiatives (Darroll, 2015). In a comparative study, Abor and Quartey (2010) noted the negative effect that red tape and weak institutional capacity had on SMME development in South Africa and Ghana. Additionally, the SAICA (2015) report on SMEs alluded to government-generated red tape in addition to compliance with the legislation and tax as problems, which have hindered the development of SMMEs in South Africa.

\subsubsection{Lack of appropriate technology}

The role that access to technology has on the development of the SMMEs is well established in the literature and particular attention has been given to its facilitation of access to both local and global markets and sharing the business information. In a related study, Fatoki and Garwe (2010) found that a lack of technological infrastructure hindered the growth of SMMEs in South Africa. Lack of technology in the SMMEs sectors has attributed to the problem of inadequate market information faced by the SMMEs operators (Oreku et al., 2009; Ocloo et al., 2014). It is, therefore, important to know that new technology is a key to the success of the SMMEs as it provides a multitude of opportunities for the SMMEs operators to explore.

\subsubsection{Xenophobia}

Targeted attacks on foreign-owned SMMEs in South Africa are on the rise, particularly in the townships where a majority of the small business in the form of spaza shops are owned by the foreign immigrants. The prevalence of xenophobic-related attacks negatively affects the growth of SMMEs in the rural areas and the townships. Studies reporting xenophobia as a plausible hindrance to the development of SMMEs have been on the rise in South Africa (see Asoba and Tengeh, 2016; Tengeh, 2016). The study highlighted the negative impact that competition and xenophobia have on immigrant-owned businesses in the local communities of South Africa.

\subsubsection{High crime rate}

The alarming crime statistics in South Africa have continued to create panic among the business people. The issue of crime has emerged in many studies and all point to the damaging effect on the growth of SMMEs in South Africa (see Fatoki and Garwe, 2010; Mukwarami and Tengeh, 2017). 


\subsubsection{Limited exposure to the international markets}

Globalisation has made available many opportunities for the SMMEs in the world. However, studies have shown that SMMEs operators are finding it difficult to access global markets, and this has led to the collapse of their business operations (Abor and Quartey, 2010). At times the ignorance of the existence of international markets compounds SMMEs' access to international markets (Fatoki and Garwe, 2010).

\subsubsection{Competition}

The business environment is quite competitive, and its effect is presumed to be moderate in markets where the playing field is level, yet this is never the case in practice. In every market situation, they are dominant players who detect the pace of innovation, pricing and so forth in a particular industry and most often act as threats to the smaller or less dominant businesses. Some studies have highlighted the downside of competition as far as the development of SMMEs is concerned. Urban and Naidoo (2012) postulate that one of the major challenges facing SMMEs operator is competition, particularly in the developing countries where small businesses are finding hard to withstand competitive pressure posed by big businesses. Concurring, Mukwarami and Tengeh (2017) advanced that native South Africans face stiff competition from immigrants owned businesses in the spaza industry.

\section{Material and methods}

Following De Vos et al. (2005), and Dana and Dana (2005), the quantitative research approach was deemed most appropriate for this study. The data was solicited through survey questionnaires. All the questions in the questionnaire were aligned the five-point Likert-scales $(1=$ strongly disagree to $5=$ strongly agree $)$. The questionnaire was pre-tested on 15 respondents and adjustments were made to the unclear items accordingly (Hilton, 2017). The questionnaires were completed with the face-to-face assistance of the interviewer and reckon that this approach this improves the quality of the information collected (Lozano et al., 2016). Following Leahy (2004), the data was recorded on a spreadsheet and later analysed through the use of Microsoft Excel function for plotting graphs.

\subsection{Population, sampling and sample size}

The population of this study comprised of SMMEs owners and managers operating in Thulamahashe, Ximhungwe, Agincoat, Malamule and Kwinyamahembe within the BLM.

Selection of the few elements of the target population is one of the ways of circumventing the challenges associated with studying the whole population. Given the two main sampling method, probability and non-probability sampling, this study used the later which Latham (2007) points out involves a careful selection of population subjects. The SMMEs owners and managers who have been in the business industry for over three years were also selected to form part of the sample. To be considered for this study, the SMME had to employ 50 or fewer employees. 
Convenient and stratified sampling was employed to recruit the respondents for this study, and this necessitated that ten respondents be selected from each of the five areas identified within the BLM.

\section{Results and discussions}

\subsection{The challenges faced by SMMEs}

The SMMEs in the BLM faces a multitude of the challenges which are categorised under different themes and summarised in Figure 2.

Figure 2 The challenges reported by the SMMEs (see online version for colours)

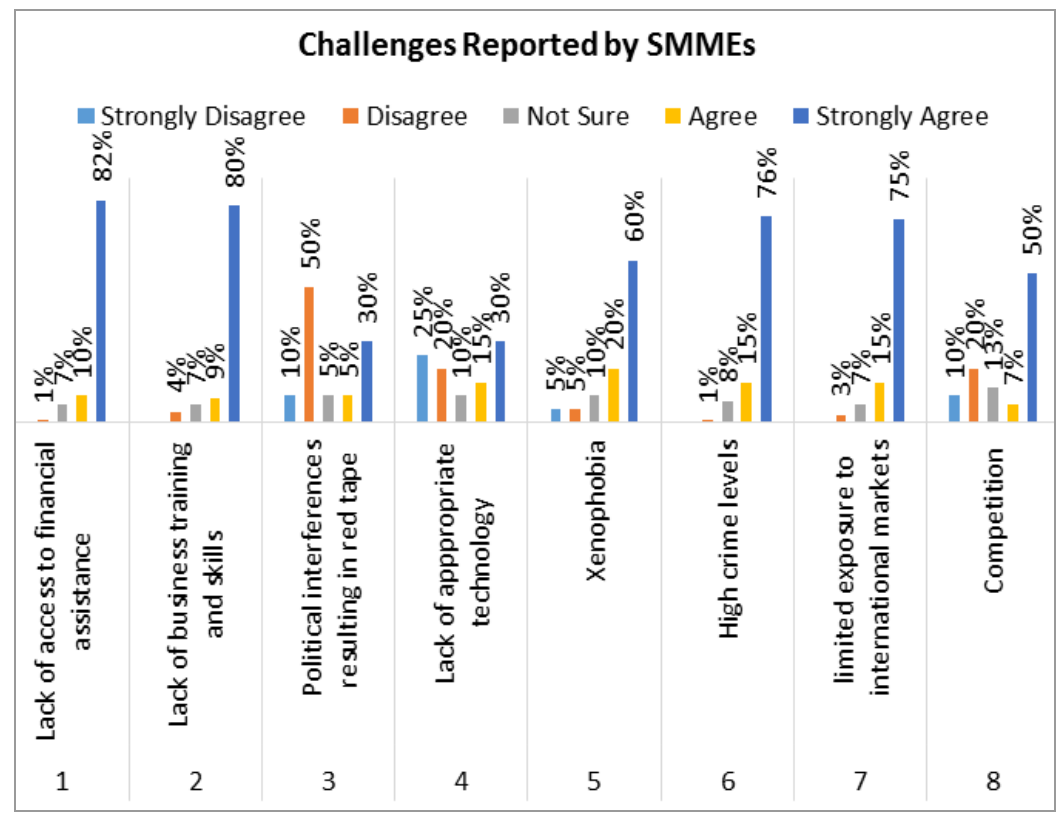

\subsubsection{Access to capital and finance}

Access to financial capital is one of the challenges which are faced by many small businesses in South Africa. An overwhelming majority of the respondents (82\%) strongly agree that financial inaccessibility hinders the growth of SMMEs in their locality. However, less than $7 \%$ of the participants were not sure if inadequate funding has an impact on SMMEs operations. Whereas, $10 \%$ agreed to the point that financial problems are significantly derailing the SMMEs growth. These findings align with Agwa-Ejon and Mbohwa's (2015) report on SMMEs in Gauteng.

\subsubsection{Managerial skills}

A sweeping majority of the respondents (89\%) concurred that a lack of managerial skills has a negative and significant effect of the growth of SMMEs in the BLM. However, 7\% 
remained neutral, and only $4 \%$ disagreed with the statement. The findings support those of Mukwarami and Tengeh (2017).

\subsubsection{High crime level}

With regards to crime, a significant number of the respondents (76\%) strongly agreed and agreed $(15 \%)$ that crime was an obstacle to the growth of businesses. Despite many respondents pointing to crime as a threat to SMMEs development, $8 \%$ and $1 \%$ remained neutral and disagreed with the point respectively. Fatoki and Garwe (2010) reported similar results in a related study.

\subsubsection{Limited exposure to global markets}

Emanating from the survey was the issue of access to global markets. Most of the respondents $(90 \%)$ reported limited exposure to global markets as a significant challenge to the growth of SMMEs in BLM. However, $7 \%$ of the respondents remained indifferent while $3 \%$ disagreed with the points that global markets inaccessibility has a negative impact on SMMEs development. Limited access to the international markets was found to negatively impact on the growth of SMMEs in South Africa and Ghana in a study done by Abor and Quartey (2010).

\subsubsection{Xenophobia}

The negative impact of xenophobia on the SMMEs operations in BLM was confirmed by a significant number of respondents $(80 \%)$. However, $10 \%$ disagreed with this points and the remaining $(10 \%)$ difference gave neutral responses. This finding confirms Asoba and Tengeh's (2016) report that xenophobia related attacks and crime pose a serious challenge to the operations of SMMEs in South Africa.

\subsubsection{Competition}

Concerning competition, a slight majority of the participants agreed $(57 \%)$ that competition poses a threat to the development of SMMEs. However, approximately $30 \%$ of the respondents disagreed while $13 \%$ of the respondents remained indifferent to the statement. The study findings are consistent with the previous literature (Asoba and Tengeh, 2016).

\subsubsection{Insufficient government support and red tape}

Contrary to popular opinion, over half of the participants $(60 \%)$ disagree that insufficient government support and red tape posed a severe challenge to the SMMEs operations in BLM. However, $35 \%$ of the respondents conceded that insufficient support and red tape have a negative impact on SMMEs development while $5 \%$ of the respondents remained indifferent. These findings are not in line with those of related studies such as Abor and Quartey (2010) and Fatoki and Garwe (2010). 


\subsubsection{Lack of appropriate technology}

Access to technology did not come up as a substantial impediment to the growth of SMMEs. While $45 \%$ of the respondent's conceded access to technology impeded the growth of SMMEs, other respondents (45\%) reported otherwise. It is worth noting that $10 \%$ of the respondents were indifferent to the statement. In this regard, those who indicated that technological inadequacy has a negative impact on SMMEs growth in BLM concur with the previous studies (Fatoki and Garwe 2010; Kongolo, 2010).

\section{Conclusions and recommendations}

While aligned with the central governments, regional governments have a significant role to play in promoting economic growth within their communities. It is widely believed that supporting SMMEs may produce the desired effect and the local municipalities are better placed to see this through. Hoping to ascertain the challenges faced by the SMMEs operators within BLM in South Africa, a survey questionnaire was administered to 50 participants drawn from the managers and owners of SMMEs operating within the municipality. The findings suggest that inaccessibility to finance, lack of managerial skills, high crime rate and inaccessibility to global markets are the most dominating obstacles to the SMMEs growth in BLM. Similarly, issues like xenophobia and competition have also been indicated as having a negative impact on SMMEs development. Contrary to other studies, lack of technological infrastructure emerged as an insignificant challenge to SMME development in the BLM.

To support the growth of SMMEs, some governments pursue LED agenda that foster infrastructure, service delivery, the establishment of business skills training centres, enacting relevant laws that promote the growth of SMMEs and small business information centres around the rural areas. Firstly, working together, policymakers, and financial institutions may address the limited access to finance debacle by promoting policies that are broad-based and inclusive. Such an initiative may necessitate schemes that encourage financial literacy among SMMEs. Secondly, training centres will be needed to equip entrepreneurs with managerial skills. Thirdly, prioritising crime prevention would be a must for the local government. Fourthly, one way of ensuring that local communities benefit from pro-SMMEs initiatives is through designing, customising and administrating appropriate LED policies.

\section{Limitations and scope of the study}

Given the fact the study focussed on the SMMEs in the rural BLM, the study findings are not a reflection of the perceptions of the SMMEs across all South African local municipalities. Perhaps this is because the various local municipalities have different LED policies which may have a different impact on the SMMEs growth. Furthermore, only a limited number of SMMEs operating within Ximhungwe, Thulamahashe, Agincoat, Kwinyamahembe and Malamule took part in the study. Given the shortcomings of this paper, it is imperative to extend the scope to include more regional municipalities to gain a deeper understanding of the challenges that SMMEs face as this may provide the basis for an integrated approach to the development of the sector. 


\section{References}

Abor, J. and Quartey, P. (2010) 'Issues in SME development in Ghana and South Africa', International Research Journal of Finance and Economics, Vol. 39, No. 6, pp.215-228.

Agwa-Ejon, J. and Mbohwa, C. (2015) 'Financial challenges faced by SMMES in Gauteng South Africa', International Association for Management of Technology, IAMOT Conference Proceedings, pp.520-534.

Asoba, S.N. and Tengeh, R.K. (2016) 'Analysis of start-up challenges of African immigrant-owned businesses in selected craft markets in Cape Town', Environmental Economics, Vol. 7, No. 2, pp.97-105.

Bowler, A., Dawood, M.S. and Page, S. (2007) Entrepreneurship and Small business Management, Juta and Co. Ltd., Pretoria.

Brinders, J., Memela, B. and Mlosy, C.D. (2003) African Renaissance 2003 Entrepreneurship and Small Business Management Development in Africa, conference held in October 2003 at Port Elizabeth, South Africa.

Brink, A., Cant, M. and Ligthelm, A. (2003) 'Problems experienced by small businesses in South Africa', 16th Annual Conference of Small Enterprises Association of Australian and New Zealand, University of Ballarat, Ballarat, Australia, 28 September-1 October.

Bushbuckridge Local Municipality (BLM) (2014) Bushbuckridge Local Municipality 2014/15 Final Integrated Development Plan [online] http://bushbuckridge.gov.za/wp-content/uploads/ 2014/04/DRAFT-BLM-IDP-2014-152.pdf (accessed 26 January 2017).

Chimucheka, T. (2015) 'The contribution of entrepreneurship education in improving entrepreneurial skills and knowledge of SMME owners and managers', Journal of Economics, Vol. 6, No. 2, pp.149-155.

Chimucheka, T. and Mandipaka, F. (2015) 'Challenges faced by small, medium and micro enterprises in the Nkonkbe Municipality', International Business \& Economic Journal, Vol. 14, No. 2, pp.309-315.

Dana, L.P. and Dana, T.E. (2005) 'Expanding the scope of methodologies used in entrepreneurship research', International Journal of Entrepreneurship and Small Business, Vol. 2, No. 1, pp.79-88.

Darroll, C. (2015) Barriers to SMEs - South Africa: OECD Economics Department Working Papers, forthcoming, OECD Publishing, Paris.

De Vos, A., Strydom, H., Fouche, C. and Delport, C. (2005) Research at Grass Roots for the Social Sciences and Human Service Professions, 3rd ed., Pretoria, Van Schaik.

Department of Cooperate Governance and Traditional Affairs (DCOGTA) (2015) Annual Report 2014/15 [online] http://www.gov.za/sites/www.gov.za/files/COGTA_Annual_Report_20142015.pdf (accessed 23 January 2017).

Department of Trade and Industry (2014) Industrial Policy Action Plan: 2013/14 - 2015/16, Pretoria.

Edwards, L. and Rankin, N. (2015) Labour Market Policies, Firm Dynamics and Export Performance in South Africa, forthcoming, OECD Economics Department Working Papers, OECD Publishing, Paris.

Fatoki, O. and Garwe, D. (2010) 'Obstacles to the growth of new SMEs in South Africa: a principal component analysis approach', African Journal of Business Management, Vol. 4, No. 5. pp.729-738.

Hilton, C.E. (2017) 'The importance of pretesting questionnaires: a field research example of cognitive pretesting the exercise referral quality of life scale (ER-QLS)', International Journal of Social Research Methodology, Vol. 20, No. 1, pp.21-34.

Kongolo, M. (2010) 'Job creation versus job shedding and the roles of SMEs in economic development', African Journal of Business Management, Vol. 4, No. 11, pp.2288-2295. 
Latham, B. (2007) Sampling: What Is It? Quantitative Research Methods [online] http://webpages.acs.ttu.edu/rlatham/Coursework/5377(Quant))/Sampling_Methodology_Paper .pdf (accessed 17 January 2015).

Leahy, J. (2004) Using Excel for Analyzing Survey Questionnaires [online] https://learningstore.uwex.edu/assets/pdfs/G3658-14.pdf (accessed 12/11/2017).

Lekhanya, M.L. (2015) 'Public outlook on small and medium enterprises as a strategic tool for economic growth and job creation in South Africa', Journal of Governance and Regulation, Vol. 4, No. 4, pp.412-418.

Lozano, F., Lobos, J.M., March, J.R., Carrasco, E., Barros, M.B. and González-Porras, J.R. (2016) 'Self-administered versus interview-based questionnaires among patients with intermittent claudication: do they give different results? A cross-sectional study', Sao Paulo Medical Journal, Vol. 134, No. 1, pp.63-69.

Mahembe, E. (2011) Literature Review on Small and Medium Enterprises' Access to Credit and Support in South Africa, Underhill Corporate Solutions (UCS) Pretoria, South Africa.

Meyer, D.F. (2014) 'Local economic development (LED), challenges and solutions: the case of the Northern Free State Region, South Africa', Mediterranean Journal of Social Sciences, Vol. 5, No. 16, pp.624-643.

Morgan, J.B. (2012) The Small and Medium Enterprise (SME) Sector - Catalyst for Growth in South Africa [online] http://www.catalystforgrowth.org/wp-content/uploads/2014/02/JPM Dalberg_SME-Catalyst-for-Growth.pdf (accessed 12 January 2017).

Mukumba, T. (2014) 'Overcoming SMEs challenges through critical success factors: a case of SMEs in the Western Cape Province, South Africa', Economic and Business Review, Vol. 16, No. 1, pp.19-38.

Mukwarami, J. and Tengeh, R.K. (2017) 'Sustaining native entrepreneurship in South Africa townships: the startup agenda', Acta Universitatis Danubius Economica), Vol. 13, No. 4, pp.332-345.

Mukwarami, S., Nyirenda, G. and Fakoya, M.B. (2017) 'The governance of corporate social responsibility and return on assets in the South Africa mining firms', African Journal of Public Affairs, Vol. 9, No.5, pp.36-153.

Mutyenyoka, E.M. and Madzivhandila, T.S. (2014) 'Employment creation through small, medium and micro enterprises (SMMEs) in South Africa: challenges, progress and sustainability', Mediterranean Journal of Social Sciences, Vol. 5, No. 25, pp.65-72.

National Planning Commission (2011) National Development Plan 2030: Executive Summary [online] https://www.gov.za/sites/default/files/Executive\%20Summary-NDP\%202030\%20$\% 20$ Our\%20future\%20-\%20make\%20it\%20work.pdf (accessed 12/11/2017).

Nyawo, J. and Mubangizi, B.C. (2015) 'Art and craft in local economic development: tourism possibilities in Mtubatuba Local Municipality', African Journal of Hospitality, Tourism and Leisure, Vol. 4, No. 2, pp.1-15.

Ocloo, C.E., Akaba, S. and Worwui-Brown, D.K. (2014) 'Globalization and competitiveness: challenges of small and medium enterprises (SMEs) in Accra, Ghana', International Journal of Business and Social Science, Vol. 5, No. 4, pp.1-10.

Oreku, G.S., Li, J., Kimeli, K. and Mtenzi, F. (2009) 'State of Tanzania e-readiness and e-commerce: an overview', Information Technology for Development, Vol. 15, No. 4, pp.302-311.

Organisation for Economic Co-operation and Development (OECD) (2015) OECD Economic Surveys: South Africa, OECD Publishing, Paris.

Ramadani, V., Dana, L., Ratten, V., and Tahiri, S. (2015) 'The context of Islamic entrepreneurship and business: concept, principles and perspectives', International Journal of Business and Globalisation, Vol. 15, No. 3, pp.244-261. 
Small Enterprise Development Agency (2016) The Small, Medium And Micro Enterprise Sector of South Africa, research note 1 [online] http://www.seda.org.za/Publications/Publications/The\% 20Small,\%20Medium\%20and\%20Micro\%20Enterprise \%20Sector\%20of\%20South\%20Africa \%20Commissioned\%20by\%20Seda.pdf (accessed 20 January 2017).

Soni, S. (2005) The Challenges Facing Small Businesses: A Global Perspective [online] http://www.dorriangroup.com (accessed 30 September 2017).

South Africa Institute of Chartered Accountants (SAICA) (2015) [online] http://www.saica.co.za/ challnges\%20of\%20SMMEs/saica_sme.pdf (accessed 23 October 2017).

Statistics South Africa (2015) Quarterly Labour Force Survey, Quarter 2, Pretoria.

Tengeh, R.K. (2013) 'Advancing the case for the support and promotion of African immigrant-owned businesses in South Africa', Mediterranean Journal of Social Sciences, Vol. 4, No. 2, pp.347-359.

Tengeh, R.K. (2016) 'Entrepreneurial resilience: the case of Somali grocery shop owners in a South African Township', Problems and Perspectives in Management, Vol. 14, No. 4, pp.203-211.

Tengeh, RK and Mukwarami, J. (2017) 'The growth challenges of native-owned spaza shops in selected townships in South Africa', International Journal of Applied Business and Economic Research, Vol. 15, No. 22, pp.61-74.

Urban, B. and Naidoo, R. (2012) 'Business sustainability: empirical evidence on SME operational skills in South Africa', Journal of Small Business and Enterprise Development, Vol. 19, No. 1, pp.146-163.

World Bank (2007) South Africa: Enhancing the Effectiveness of Government in Promoting Micro, Small and Medium Enterprises, World Bank, Washington, DC. 